\title{
Chapter 4 \\ Conversion of Be-7 Activity \\ Concentrations into Soil and Sediment \\ Redistribution Amounts
}

\author{
W. H. Blake, A. Taylor, A. R. Iurian, G. E. Millward and L. Mabit
}

\subsection{Implementing the Event-Scale Profile Distribution Model}

The Profile Distribution Model (PDM) is described in detail by Walling and He (1999) and Blake et al. (1999). Here, alongside an overview of the basic components, we provide step-by-step guidance to its implementation and simple encoding within Microsoft Excel.

This simple conversion model relies on exponential decline in ${ }^{7} \mathrm{Be}$ activity concentration with depth wherein the shape of the profile is described by $h_{0}$ (See Chap. 1 , Sect. 1.2). A first necessary step is to establish a specific $h_{0}$ value for the site under investigation. This can be achieved by plotting the depth profile from your reference area as an $\mathrm{x}-\mathrm{y}$ plot and fitting an exponential function (see Table 4.1 and Fig. 4.1).

W. H. Blake $(\bowtie)$

School of Geography, Earth and Environmental Sciences, University of Plymouth, Plymouth, UK e-mail: william.blake@plymouth.ac.uk
A. Taylor · G. E. Millward
Consolidated Radioisotope Facility (CoRiF), University of Plymouth, Plymouth, UK
e-mail: alex.taylor@plymouth.ac.uk
G. E. Millward
e-mail: G.Millward@plymouth.ac.uk

\author{
A. R. Iurian \\ Terrestrial Environment Laboratory, IAEA Laboratories Seibersdorf, Seibersdorf, Austria \\ e-mail: A.Iurian@iaea.org \\ L. Mabit \\ Soil and Water Management and Crop Nutrition Subprogramme, Joint FAO/IAEA Division of \\ Nuclear Techniques in Food and Agriculture, International Atomic Energy Agency, Vienna, \\ Austria \\ e-mail: L.Mabit@iaea.org
}

(C) International Atomic Energy Agency (IAEA) 2019 
Table 4.1 Example of the depth profile data used in Fig. 4.1 where the ${ }^{7} \mathrm{Be}$ concentrations have been determined with a 2-sigma error

\begin{tabular}{l|l|l|l|l|l}
\hline $\begin{array}{l}\text { Nominal true } \\
\text { depth }(\mathrm{mm})\end{array}$ & $\begin{array}{l}\text { Total dry } \\
\text { mass } \\
(<2 \mathrm{~mm})(\mathrm{g})\end{array}$ & $\begin{array}{l}\text { Mass depth } \\
\left(\mathrm{kg} \mathrm{m}^{-2}\right)\end{array}$ & $\begin{array}{l}\text { Cumulative } \\
\text { mass depth } \\
\left(\mathrm{kg} \mathrm{m}^{-2}\right)\end{array}$ & $\begin{array}{l}7 \text { Be activity } \\
\text { concentration } \\
\left(\mathrm{Bq} \mathrm{kg}^{-1}\right)\end{array}$ & $\begin{array}{l} \pm(2 \\
\text { sigma })^{\mathrm{a}}\end{array}$ \\
\hline 2 & 83.84 & 0.93 & 0.93 & 70.02 & 4.5 \\
\hline 4 & 76.17 & 0.85 & 1.78 & 61.85 & 5.0 \\
\hline 6 & 90.14 & 1.00 & 2.78 & 46.91 & 5.2 \\
\hline 8 & 84.71 & 0.94 & 3.72 & 52.51 & 5.2 \\
\hline 10 & 165.91 & 1.84 & 5.56 & 48.06 & 4.4 \\
\hline 12 & 156.87 & 1.74 & 7.31 & 48.62 & 6.2 \\
\hline 14 & 175.54 & 1.95 & 9.26 & 24.89 & 5.0 \\
\hline 16 & 204.27 & 2.27 & 11.53 & 19.52 & 5.7 \\
\hline 18 & 162.85 & 1.81 & 13.34 & 11.03 & 5.4 \\
\hline 20 & 214.66 & 2.39 & 15.72 & 10.13 & 5.2 \\
\hline
\end{tabular}

analytical uncertainty

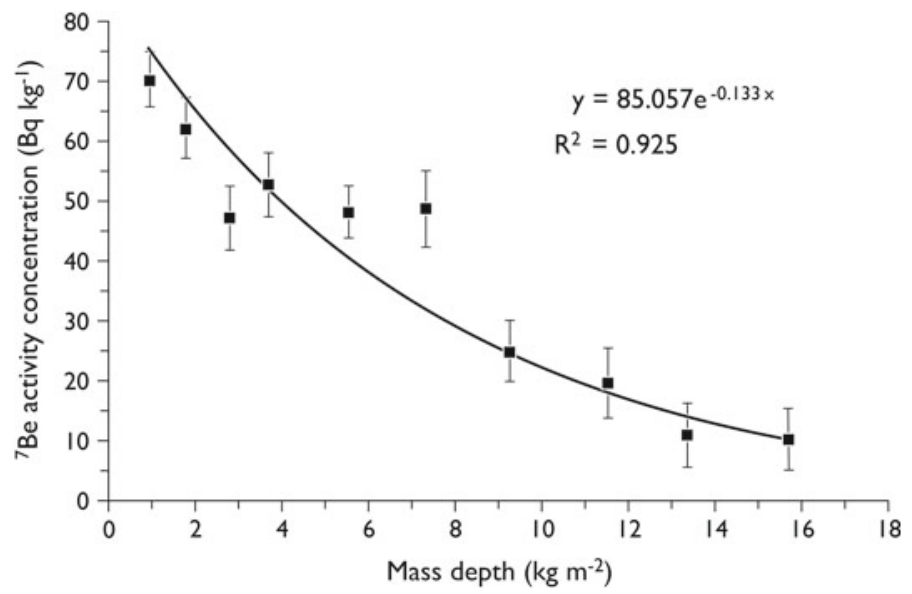

Fig. 4.1 ${ }^{7}$ Be activity concentration against mass depth with a fitted exponential line to derive the value of $h_{0}$

It is important that measures of depth are represented as mass depth i.e. mass of soil for the core slice divided by the area of the core with units of $\mathrm{kg} \mathrm{m}^{-2}$. This accounts for changes in bulk density and is a more precise measure of depth than true depth. $h_{0}$ is derived by taking the reciprocal of the exponent of the line. In the case of the depth profile shown in Fig. 4.1, $h_{0}$ is derived from:

$$
\frac{1}{0.133}=7.5\left(\mathrm{~kg} \mathrm{~m}^{-2}\right)
$$


Table 4.2 An example grid cell layout with example inventory data ( \pm is analytical uncertainty) where coding presented in Table 4.3 is required to determine $h, C_{d}$ and $h^{\prime}$ (see Chap. 1, Appendix 1.1), without particle size correction. Calculated values following Table 4.3 are shown in italics

\begin{tabular}{|c|c|c|c|c|c|c|c|}
\hline & A & B & C & D & $E$ & $F$ & G \\
\hline 1 & $\underset{\text { ID }}{\text { Sample }}$ & $\begin{array}{c}\begin{array}{c}{ }^{7} \mathrm{Be} \\
\text { inventory }\end{array} \\
\left(\mathrm{Bq} \mathrm{m}^{-2}\right)\end{array}$ & \pm & $\begin{array}{c}\text { Uncorrected } \\
\text { erosion } \\
\text { amount }(h) \\
\left(\mathrm{kg} \mathrm{m}^{-2}\right)\end{array}$ & $\begin{array}{c}\text { Eroded soil } \\
{ }^{7} \text { Be activity } \\
\text { conc. } \\
\left(\mathrm{Bq} \mathrm{kg}^{-1}\right)\end{array}$ & $\begin{array}{c}\text { Deposited } \\
\text { soil }{ }^{7} \mathrm{Be} \\
\text { activity conc, } \\
\left(C_{d}\right) \\
\left(\mathrm{Bq} \mathrm{kg}^{-1}\right)\end{array}$ & $\begin{array}{c}\text { Uncorrected } \\
\text { deposition } \\
\text { amount }\left(h^{\prime}\right) \\
\left(\mathrm{kg} \mathrm{m}^{-2}\right)\end{array}$ \\
\hline 2 & 1 & 184 & 38 & 7.85 & 43.32 & & \\
\hline 3 & 2 & 394 & 56 & 2.14 & 60.79 & & \\
\hline 4 & 3 & 300 & 43 & 4.18 & 53.55 & & \\
\hline 5 & 4 & 216 & 34 & 6.65 & 46.34 & & \\
\hline 6 & 5 & 304 & 52 & 4.08 & 53.88 & & \\
\hline 7 & 6 & 279 & 45 & 4.73 & 51.83 & & \\
\hline 8 & 7 & 361 & 101 & 2.79 & 58.33 & & \\
\hline 9 & 8 & 397 & 103 & 2.08 & 61.01 & & \\
\hline 10 & 9 & 330 & 69 & 3.47 & 55.94 & & \\
\hline 11 & 10 & 435 & 98 & 1.40 & 63.75 & & \\
\hline 12 & 11 & 817 & 102 & & & 51.82 & 5.65 \\
\hline 13 & 12 & 1070 & 96 & & & 51.82 & 10.54 \\
\hline
\end{tabular}

To run the PDM in Excel, the key components of the model can be coded into a cell grid as illustrated in Table 4.2. In this example, the reference inventory value is set at $524 \pm 46 \mathrm{~Bq} \mathrm{~m}^{-2}$ ( $\mathrm{n}=15$ where uncertainty represents 2 standard deviations). The sample points 1-10 are erosional (i.e. an inventory deficit as compared to the activity recorded in the reference area) and sample points 11 and 12 are depositional (i.e. an inventory excess as compared to the activity recorded in the reference area).

Coding required for columns D, E, F and G to calculate $h, C_{d}$ and $h^{\prime}$ respectively (see Chap. 1, Appendix 1.1 for relevant model equations) is provided in Table 4.3.

The PDM may also be applied using a specific Microsoft Excel Addin — developed by Walling and He (1999) and refined by Walling et al. (2002)—which is available at the IAEA website (see http://www-naweb.iaea.org/nafa/swmn/modelstool-kits.html).

\subsection{Accounting for Size Selectivity of Erosion and Deposition Processes in the Profile Distribution Model}

As pointed out in the Sect. 2.4 of the Chap. 2, some advanced users will need to account for particle size selectivity associated with soil erosion processes to convert inventory loss into soil erosion amounts. Different approaches are described in the literature (see Taylor et al. 2014 or Yang et al. 2013). Here, we describe the method 
Table 4.3 Coding for columns D, E, F and G in Table 4.2 to derive the key elements of the PDM as described in Sect. 1.2

\begin{tabular}{|c|c|c|}
\hline $\begin{array}{l}\text { Cell number } \\
\text { (assuming } \\
\text { layout as per } \\
\text { Table 4.2) }\end{array}$ & Code & Explanation \\
\hline D2 & $\begin{array}{l}=\$ \mathrm{I} \$ 2 * \mathrm{LN}(\$ \mathrm{I} \$ 3 / \mathrm{B} 2)(\mathrm{see} \\
\text { Chap. } 1 \text { Eq. } 1.3)\end{array}$ & $\begin{array}{l}\text { This Excel code is to derive ' } h \text { ' i.e. the } \\
\text { mass depth of soil lost (NB as positive } \\
\text { value) i.e. Aref/A to account for the } \\
\text { observed inventory deficit in cell } \mathrm{D} 2 \\
\text { where cell } \mathbf{I} 2 \text { contains the value for } \mathbf{h}_{\mathbf{0}} \\
\text { (in this example } \mathbf{7 . 5} \mathbf{k g ~ m}^{-\mathbf{2}} \text { ) and cell } \mathbf{I} 3 \\
\text { contains the reference inventory (in } \\
\text { this case } \mathbf{A}_{\text {ref }}=\mathbf{5 2 4} \text { Bq } \mathbf{m}^{-\mathbf{2}} \text { ). Note that } \\
\text { this code can then be copied down to all } \\
\text { eroding site points }\end{array}$ \\
\hline E2 & $\begin{array}{l}=(\$ \mathrm{I} \$ 3-\mathrm{B} 2) / \mathrm{D} 2(\mathrm{see} \\
\text { Chap. } 1 \text { Eq. 1.5) }\end{array}$ & $\begin{array}{l}\text { This Excel code permits to estimate the } \\
{ }^{7} \mathrm{Be} \text { concentration of the soil eroded from } \\
\text { this sample point or zone }\end{array}$ \\
\hline F11 & $\begin{array}{l}=(\mathrm{D} 2 * \mathrm{E} 2)+\ldots+(\mathrm{D} 11 * \mathrm{E} 11)) / \\
\text { SUM }(\mathrm{D} 2: \mathrm{D} 11)(\text { see } \\
\text { Chap. } 1 \text { Eq. 1.6) }\end{array}$ & $\begin{array}{l}\text { This Excel code allows to calculate the } \\
\text { mean activity concentration of upslope } \\
\text { eroded soil used in the equation for } h^{\prime} \\
\text { below. Note that all upslope contributing } \\
\text { points need to be included in the code } \\
\text { across (shown in shortened form). This } \\
\text { needs to be copied for all depositional } \\
\text { points }\end{array}$ \\
\hline G12 & $\begin{array}{l}=(\mathrm{B} 12-\$ \mathrm{I} \$ 3) / \mathrm{F} 12(\mathrm{see} \\
\text { Chap. } 1 \mathrm{Eq} .1 .4)\end{array}$ & $\begin{array}{l}\text { This is to calculate } \mathrm{h}^{\prime} \text { i.e. the mass depth } \\
\text { of soil gained to account for the inventory } \\
\text { excess in cell D11. This needs to be } \\
\text { copied for all depositional points }\end{array}$ \\
\hline
\end{tabular}

proposed by Taylor et al. (2014) and compare to other methods so users can make an informed decision about which approach to take.

The PDM assumes that the soil profile is top-sliced by erosion and that loss of inventory is directly related to the mass depth of soil lost (see Fig. 1.3). However, enrichment of ${ }^{7} \mathrm{Be}$ in fine soil fractions (Fig. 4.2) means that these can be preferentially removed by erosion processes resulting in an augmented inventory deficit relative to erosion amount (Blake et al. 2009; Taylor et al. 2014). It should be noted that in some cases where soil has an overall fine texture and rainfall is of high magnitude, particle size correction may be less important (e.g. Porto and Walling 2014)

The approach suggested by Taylor et al. (2014) accounting for particle size selectivity follows the principles of the method proposed by $\mathrm{He}$ and Walling (1996) wherein particle size correction factors $\mathrm{P}$ and $\mathrm{P}^{\prime}$ for eroding and depositional sites respectively are calculated based on measurements of 'geometric' Specific Surface Area (SSA unit in $\mathrm{m}^{2} \mathrm{~g}^{-1}$ ). $\mathrm{P}$ is derived from: 
Fig. 4.2 Enrichment of stable $\mathrm{Be}$, as a surrogate for ${ }^{7} \mathrm{Be}$, in two fine grained soil materials with contrasting texture where soil A has a greater sand content (Taylor et al. 2014)

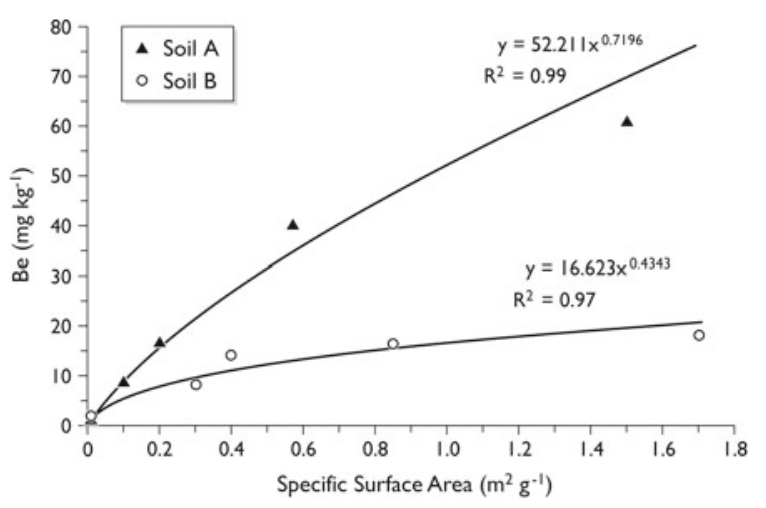

$$
P=\left(\frac{S_{m}}{S_{s}}\right)^{v}
$$

where $S_{m}$ is the mean SSA of the mobilised fraction and $S_{s}$ is the mean SSA of the bulk soil material and $v$ is a constant describing the relationship (i.e. the power function exponent) between ${ }^{7} \mathrm{Be}$ concentration and SSA (Fig. 4.2).

$P^{\prime}$ is derived from:

$$
P^{\prime}=\left(\frac{S_{d}}{S_{m}}\right)^{v}
$$

where $S_{d}$ is the mean SSA of the deposited material.

The SSA of soil and sediment samples is most commonly performed using laser granulometry. It is also possible to derive SSA from particle size data derived by gravitational sedimentation methods, most commonly the pipette method (Day 1965).

It is important at this stage to consider that amounts of erosion estimated using a conversion model consider inventory deficit i.e. the amount of ${ }^{7} \mathrm{Be}$ inventory lost from a specific area due to soil erosion. This inventory deficit is converted to mass depth soil loss using the exponential shape of the ${ }^{7} \mathrm{Be}$ distribution in the soil profile (Eq. 1.1). In this context, Taylor et al. (2014) propose that when correcting erosion rates (mass depth lost, $\mathrm{kg} \mathrm{m}^{-2}$ ) for particle size enrichment it is, therefore, necessary to apply the correction factor to the inventory deficit only (i.e. A minus $A_{\text {ref }}$ ) which has the effect of suppressing the loss in inventory according to the particle size of the fraction mobilised. If fine sediment is preferentially mobilised by erosion processes, failure to account for this will lead to overestimation of erosion.

In the case of the above, following the principles of He et al. (2002), a particle-size corrected erosion rate, $h_{c}$, can be calculated using the following equation (compare to Eq. 1.2):

$$
h_{c}=h_{0} \ln \frac{A_{r e f}}{A_{r e f}-\left(A_{r e f}-A\right) / P}
$$


For estimates of deposition, the ${ }^{7} \mathrm{Be}$ concentration of deposited material needs to be adjusted according to the particle size of the deposited fraction relative to the eroded fraction. The equation to provide corrected deposition rates, $h_{c}^{\prime}$, is (compare to Eq. 1.4):

$$
h_{c}^{\prime}=\left(A-A_{r e f}\right) / C_{d, c}
$$

where $C_{d, c}$ is the weighted mean concentration of sediment mobilised from the upslope contributing area (Blake et al. 1999; Walling et al. 1999) which has been corrected for particle size enrichment during erosion, and then corrected for depletion during deposition (He et al. 2002). The particle size corrected concentration of deposited material from an individual eroding point $\left(c d^{\prime}\right)$ can be estimated using the following function:

$$
c d^{\prime}=P P^{\prime} A_{r e f}\left(1-e^{-h / h_{0}}\right) / h
$$

These data processing requirements need to be considered in the context of the sampling challenges detailed in Chap. 2.

The above equations can be used to modify the Excel-based PDM model coding provided in Table 4.3 .

There are several challenges with particle size correction that all users must be aware of. Determining the relationship between the activity concentration and SSA to gain the value of the exponent, $v$, in Eqs. (4.1) and (4.2), requires particle size separation experiments (Taylor et al. 2014) and use of a laser granulometer or quantitative sieving (and application of SSA theory which makes assumptions about particle sphericity). Sampling for $S_{s}$ and $S_{d}$ is relatively straightforward (sampled in field from stable and deposition sites) but sampling for $S_{m}$ is less straightforward. Options for this include rainfall simulation experiments on the hillslope after the erosion event to collect representative eroded material, installation of Gerlach troughs in study field prior to anticipated erosion events or estimating SSA of eroded material from remaining soil-and comparison with uneroded material (see Yang et al. 2013)

All particle size corrections require a necessary simplification of reality since soil characteristics are highly variable within and between sites. Example data illustrating the influence of particle size correction approaches on soil erosion estimate results are given in Sect. 4.4 .

\subsection{Extended Time Series Conversion Model: The Theory}

If an advanced user wishes to apply the ${ }^{7} \mathrm{Be}$ approach over a longer time period, for example over a wet season that contains notable erosional events in series, an alternative approach is required (Walling et al. 2009). Modifications to the PDM approach are required to account for inventory flux $\left(\mathrm{Bq} \mathrm{m}^{-2}\right)$, decay and the erosivity of events. 
Fig. 4.3 Relationship between the percentage under-estimation of the erosion rate versus the length of the study period (from Walling et al. 2009)

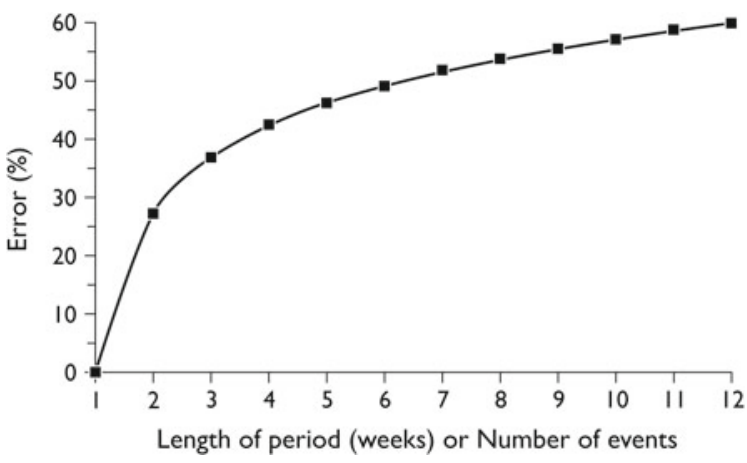

Failure to account for these factors has been shown to lead to underestimation of redistribution rates (Walling et al. 2009). In this approach, the cumulative change in inventory at the sample site is considered rather than a direct comparison to the stable reference value for each day. A reference inventory for the field site is required, however, to provide an indication of erosion or deposition at each individual sample location.

The basic principle of the extended time-series model is that the amount of erosion estimated by ${ }^{7} \mathrm{Be}$ inventory deficit and deposition estimated by ${ }^{7} \mathrm{Be}$ inventory excess needs to be apportioned across the time period of study while allowing for the effects of radioactive decay. The problem of the PDM over extended time periods is considered by Walling et al. (2009) for a hypothetical scenario where: (1) the reference inventory begins at zero due to extended dry period, (2) a single rainfall event of same intensity takes place each week with same erosivity, (3) $h_{0}$ remains the same. The results (Fig. 4.3) demonstrate that the ${ }^{7} \mathrm{Be}$ approach increasingly underestimates the erosion rate with substantial error as time progresses into the study period (e.g. $30 \%$ after 2-3 weeks; $50 \%$ after 3 months). In addition to this issue of decay of the earlier erosion event signals, there are other potential complications linked to temporal distribution of ${ }^{7} \mathrm{Be}$ during the study period, temporal distribution of erosion (rainfall erosivity), potential variability of other key parameters through time, especially on freshly ploughed surface, e.g. $h_{0}$.

In this context, every user needs to consider the sensitivity of their study data to these issues and either take action or acknowledge these limitations and the uncertainty introduced into their results.

In this section we present a step-by-step approach to implementing the extended time series model in Microsoft Excel based on Walling et al. (2009). There are three main components: (1) calculating relative erosivity of rainfall, (2) estimating soil loss and (3) estimating deposition.

The aim of the extended time series model is to allow ${ }^{7} \mathrm{Be}$ measurements to be extended over a longer timeframe that is more representative for some environments for example where erosion takes place over a prolonged wet season.

In addition to the evidence collected for the PDM, the extended time series model requires a reconstructed record of daily fallout deposition $\left(B q m^{-2} \mathrm{~d}^{-1}\right)$ for the 
whole study period and a time series of daily (where appropriate) relative erosivity (see below). Together, these account for the effects of time variant erosion and the time variant fallout as well as for the radioactive decay.

The first step in applying the model is the same as for the PDM (Sect. 4.1) namely to determine whether the site is erosional or depositional i.e. compare inventory at erosional point $(A)$ or depositional point $\left(A^{\prime}\right)$ to reference inventory $A_{\text {ref }}$.

The second step is to build a mass balance model framework used to define the ${ }^{7} \mathrm{Be}$ inventory at the end of each day $A(t)\left(\mathrm{Bq} \mathrm{m}^{-2}\right)$. This is determined from: (i) the ${ }^{7} \mathrm{Be}$ inventory of the previous day $[A(t-1)]$, (ii) effects of radioactive decay $[\lambda]$, (iii) any fallout input (that day $[F(t)]$, (iv) any loss in ${ }^{7} \mathrm{Be}$ inventory due to erosion $\left[A_{\text {loss }}\right]$. Of course, the mass balance must ultimately be solved for the latter element. These components are linked together as follows:

$$
A(t)=A(t-1) \exp (-\lambda)+F(t)-A_{\text {loss }}(t)
$$

$\mathrm{A}_{\text {loss }}(\mathrm{t})$ in Eq. (4.6) will reflect (i) amount of soil eroded $[R(t)]$ as a mass depth i.e. $\mathrm{kg} \mathrm{m}^{-2}$, (ii) existing inventory at the point $[A(t)]$, and (iii) depth distribution of inventory i.e. $h_{0}$ (for that day) i.e.:

$$
A_{\text {loss }}(t)=[A(t-1) \exp (-\lambda)+F(t)] *\left[1-\exp \left(-\frac{R(t)}{h_{0}(t)}\right)\right]
$$

In the prior equations, the amount of soil eroded $R(t)$ is assumed to be proportional to the rainfall erosivity for that daily time-step and can be expressed as following:

$$
R(t)=E_{r}(t) * C
$$

In Eq. (4.8), $C$ is a constant that links relative erosivity (i.e. $\mathrm{E}_{\mathrm{r}}$ ) to erosion amount. The value of $C$ differs between sample points but at any one sample point it remains constant through the study period.

To derive $C$ and hence $R(t)$, the user must establish a continuous mass balance for the study period for each sampling point experiencing erosion. Guidance on setting this up in Microsoft Excel is given in the next section. The value of $A(t)$ at the end of the study can then be related to the measured inventory $(A)$ at the time of sampling. Note the value at the start is equal to the measured reference inventory at the beginning of the study (often zero due to cultivation of extended dry period). Given all the data that have been derived up to this point, the mass balance can be solved for $C$ using the optimising Solver routine in Microsoft Excel. This so called 'what-if analysis' tool basically finds the optimum value of $\mathrm{C}$ to explain the measured inventory within the constraints of the mass balance detailed in the worksheet.

Application of $C$ to the $E_{r}(t)$ values in the time series then gives the estimated erosion amount for the sample point. An example of spreadsheet coding is given in Sect. 4.4. 
As noted above, in the extended time-series model, a key part of the process is using rainfall erosivity to apportion erosion potential across the study period. For the study period in question, a measure of relative erosivity is required for each event occurring during the study period.

Arguably, we need knowledge of site specific thresholds for erosion initiation based on rainfall patterns and dynamics and site-specific conditions need consideration e.g. runoff initiation processes. Walling et al. (2009) used high resolution rainfall data (minimum 30 min interval data) to evaluate temporal distribution of erosivity $\left(E_{r}\right)$. This approach is linked to RUSLE daily values of erosivity based on the product of the total kinetic energy of rainfall $(E)$ and maximum 30 min rainfall intensity $\left(I_{30}\right)$ i.e. $E I_{30}$. This means a continuous rainfall record at study site is required (30 min totals). It should be noted that a measure of relative erosivity in this context is more important than an absolute value. Local empirical data, if available, may be more appropriate at some sites. Taylor (2012) followed procedures outlined by Yin et al. (2007) and Morgan (2001) to derive $E I_{30}$ following Schuller et al. (2010).

\subsection{Implementing the Extended Time Series Model}

The extended time series model can be implemented in a variety of ways. We propose here one version for coding in Microsoft Excel as an example to develop from. Such an approach permits the user to see the model working step-by-step and to troubleshoot any coding errors or data anomalies that emerge.

The model structure comprises a series of columns that represent the time series of daily fallout, erosion etc. (Table 4.4) and a set of 'model interface' cells where primary data is inputted and results are calculated.

To permit cell O7 to show the most likely erosion rate, the Solver Routine must be run. This requires the actual measured inventory at the sample point to be entered into the Solver dialogue box (Fig. 4.4) and the routine run so the value of O5 is adjusted to equal the measured inventory. The routine does this by adjusting the unknown constant $\mathrm{C}$ until the value of $\mathrm{O} 7$ is equal to the inventory measured.

The extended time series model is an appropriate approach to address the challenge of using ${ }^{7} \mathrm{Be}$ across multiple rainfall events. In addition to the requirements of the $\mathrm{PDM}$, it requires rainfall data and site-specific determination of relative erosivity. Implementation of this advanced model requires careful coding and usage of data. Users need to be aware of specific sample point attributes and relationships to other points and to ensure that each working step is traceable in case of a need to revisit data. 
Table 4.4 Microsoft Excel coding for time series and mass balance columns. It is assumed user has a basic knowledge of Microsoft Excel and that the column headings are entered in the first row

\begin{tabular}{|c|c|c|}
\hline Cell number & Code & Column title and explanation \\
\hline $\begin{array}{l}\text { A2 (and relevant } \\
\text { cells below) }\end{array}$ & $\mathrm{n} / \mathrm{a}$ & $\begin{array}{l}\text { Date of time step (in DD/MM/YYYY format). } \\
\text { This should be copied down for the duration of } \\
\text { the study period from the start of rainfall } \\
\text { measurement to the final erosion event to be } \\
\text { studied }\end{array}$ \\
\hline $\begin{array}{l}\text { B2 (and relevant } \\
\text { cells below) }\end{array}$ & $\mathrm{n} / \mathrm{a}$ & $\begin{array}{l}\text { Daily inventory fallout flux }(F) \text { value } \\
\left(\mathrm{Bq} \mathrm{m}^{-2}\right) \text { which has been derived from a } \\
\text { rainfall measurement and sampling programme } \\
\text { described in Chap. } 2\end{array}$ \\
\hline $\begin{array}{l}\mathrm{C} 2 \text { (and relevant } \\
\text { cells below) }\end{array}$ & $=0.0130$ & Decay constant for ${ }^{7} \mathrm{Be}$ for 1 day time step \\
\hline $\mathrm{D} 2$ & $\mathrm{n} / \mathrm{a}$ & $\begin{array}{l}\text { The study area initial plot reference inventory } \\
\text { at the start of the rainfall measurement and } \\
\text { monitoring, typically zero }\left(\mathrm{Bq} \mathrm{m}^{-2}\right)\end{array}$ \\
\hline D3 & $=\mathrm{B} 3+(\mathrm{D} 2 * \mathrm{EXP}(-\mathrm{C} 3 * 1))$ & $\begin{array}{l}\text { Daily reference inventory for time step based } \\
\text { on decay corrected inventory from prior day } \\
\text { plus the fallout input of the current day } \\
\left(\mathrm{Bq}^{-2}\right) \text {. Note this column is copied down to } \\
\text { the end of the study period }\end{array}$ \\
\hline $\begin{array}{l}\text { E2 (and relevant } \\
\text { cells below) }\end{array}$ & $\mathrm{n} / \mathrm{a}$ & $\begin{array}{l}\text { Relative Erosivity }\left(E_{r}\right) \text { value for the timestep. } \\
\text { Note that all } E_{r} \text { values in the column will sum } \\
\text { to } 1 . \text { Note this column is copied down to the } \\
\text { end of the study period }\end{array}$ \\
\hline $\mathrm{F} 2$ & $=\$ O \$ 2$ & $\begin{array}{l}\text { Constant } C \text {. Note this code links it to a cell in } \\
\text { the model 'interface' cells. Note this column is } \\
\text { copied down to the end of the study period }\end{array}$ \\
\hline G2 & $=\mathrm{E} 2 * \mathrm{~F} 2$ & $\begin{array}{l}\text { Relative Erosion Rate }(R) \text {. Note this column is } \\
\text { copied down to the end of the study period }\end{array}$ \\
\hline $\begin{array}{l}\mathrm{H} 2 \text { (and relevant } \\
\text { cells below) }\end{array}$ & $=\mathrm{G} 2 / \$ \mathrm{O} \$ 3$ & $\begin{array}{l}\text { Particle size corrected relative erosion rate } \\
\text { where cell O3 contains the simple correction } \\
\text { factor } P \text { in the model 'interface' cells area } \\
\text { (based on Yang et al. 2013). See Sect. } 4.2 \text {. Note } \\
\text { this column is copied down to the end of the } \\
\text { study period }\end{array}$ \\
\hline $\mathrm{I} 2$ & $=(\mathrm{D} 2) *(1-\operatorname{EXP}(\mathrm{G} 2 / \$ O \$ 4))$ & $\begin{array}{l}\text { Inventory loss }\left(\mathrm{A}_{\text {loss }}\right)\left(\mathrm{Bq} \mathrm{m}^{-2}\right) \text { where cell } \mathrm{O} 4 \\
\text { contains the value of } h_{0} \text {. This is for first time } \\
\text { step. For following time steps, cell } \mathrm{I} 3 \text { then } \\
\text { needs updating as below to account for decay } \\
\text { or previous time-step }\end{array}$ \\
\hline $\mathrm{I} 3$ & $\begin{array}{l}=(\mathrm{J} 2 * \operatorname{EXP}(-\mathrm{C} 3)+\mathrm{B} 3) *(1- \\
\operatorname{EXP}(\mathrm{G} 3 / \$ \mathrm{O} \$ 4))\end{array}$ & $\begin{array}{l}\text { Note this column is copied down to the end of } \\
\text { the study period }\end{array}$ \\
\hline $\mathrm{J} 2$ & $=\mathrm{D} 2-\mathrm{I} 2$ & $\begin{array}{l}\text { Modelled inventory }(A)\left(\mathrm{Bq} \mathrm{m}^{-2}\right) \text { for first time } \\
\text { step. For following time steps, see cell } \mathrm{J} 3 \text { as } \\
\text { below to account for decay or previous } \\
\text { time-step }\end{array}$ \\
\hline $\mathrm{J} 3$ & $=\mathrm{J} 2 * \mathrm{EXP}(-\mathrm{C} 3 * 1)+\mathrm{B} 3-\mathrm{I} 3$ & $\begin{array}{l}\text { Note this column is copied down to the end of } \\
\text { the study period }\end{array}$ \\
\hline K2 & $=\mathrm{IF}(\mathrm{G} 2<>0, \mathrm{I} 2 / \mathrm{G} 2,0) * \$ \mathrm{O} \$ 3$ & $\begin{array}{l}\text { Activity of eroded soil }\left(\mathrm{C}_{\mathrm{e}}\right)\left(\mathrm{Bq} \mathrm{kg}^{-1}\right) \text {. This is } \\
\text { used in deposition calculations downslope }\end{array}$ \\
\hline
\end{tabular}




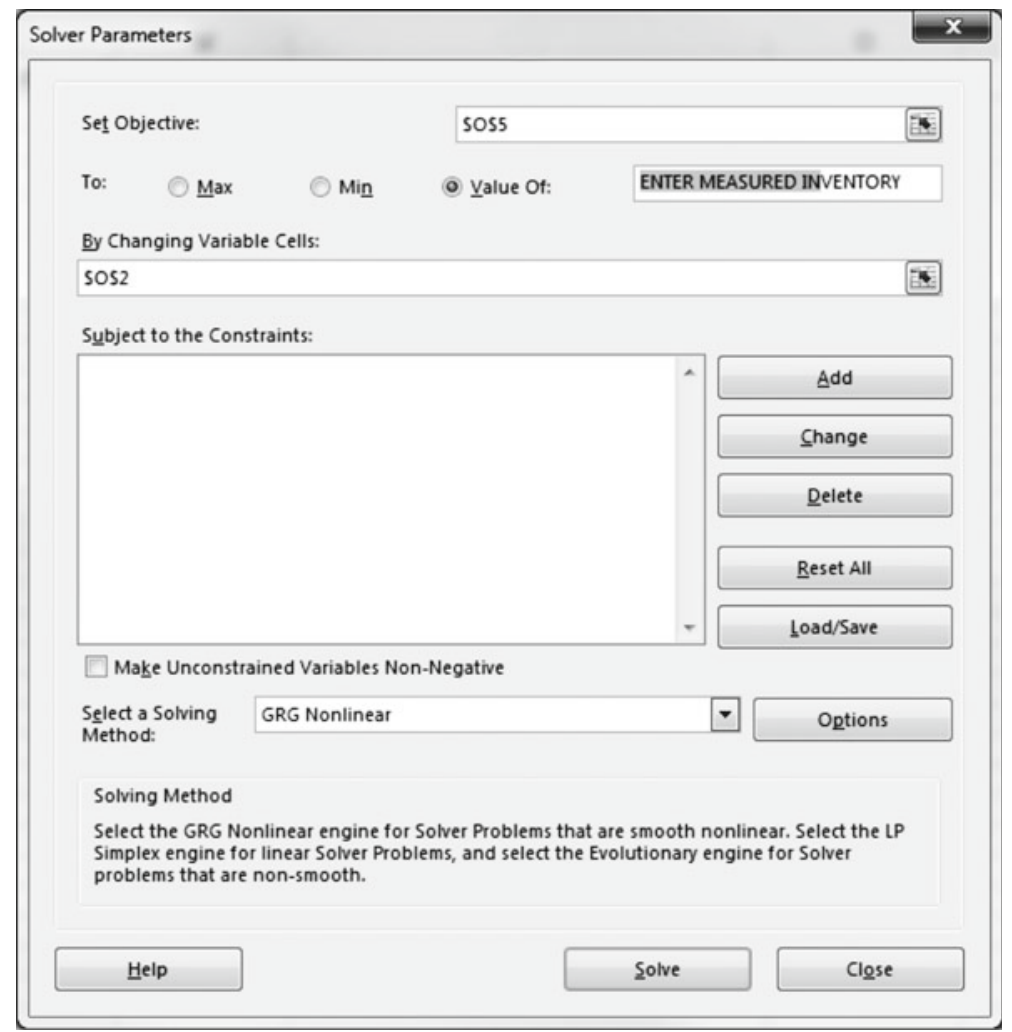

Fig. 4.4 Dialogue box for Miscrosoft Excel Solver command set up to work with the user interface cells in Table 4.5. Note where the value of the measured inventory needs to be entered

\subsection{Hillslope Sediment Budget Examples and Inclusion of Uncertainty}

The data presented in Table 4.2 can be used to check model coding by comparing model outputs derived with this dataset to the results presented in Table 4.6. It is important to note that Table 4.6 is provided for checking of the central result only and does not include an uncertainty. It is critical that users report their soil erosion estimates with an appropriate uncertainty and that the means by which the uncertainty has been determined is transparent to the reader of reports and subsequent publications.

Uncertainty can be derived from a range of different factors within the sampling and analysis process (Fig. 4.5). The most obvious source of uncertainty is the analytical error originating from the gamma spectrometry measurement (see Chap. 3) which can easily be propagated through to the resulting soil erosion estimate. This is, however, arguably less environmentally relevant than other factors. An alternative 
Table 4.5 Microsoft Excel coding for user interface cells (linked to cells described in Table 4.4). Note that until the Microsoft Excel Solver is run using the coding provided below, the numbers in the results cell are arbitrary. Using the 'Solver' command the modelled inventory can be fitted to the measured inventory to allow cell $\mathrm{O} 5$ to equal the sample point inventory by changing the constant. Values of $h_{0}$ and particle size correction can be changed manually in cells O3-4 for scenario testing

\begin{tabular}{|c|c|c|}
\hline $\begin{array}{l}\text { Cell } \\
\text { number }\end{array}$ & Code & Column title and explanation \\
\hline $\mathrm{O} 2$ & Enter any start value e.g. 1 & $\begin{array}{l}\text { Cell where value of } C \text { will be calculated } \\
\text { by the Solver routine }\end{array}$ \\
\hline O3 & $\mathrm{n} / \mathrm{a}$ & $\begin{array}{l}\text { Enter particle size correction factor } P \\
\text { (enter } 1 \text { if no correction required) }\end{array}$ \\
\hline $\mathrm{O} 4$ & $\mathrm{n} / \mathrm{a}$ & Enter value of $h_{0}$ \\
\hline O5 & $\begin{array}{l}\text { Enter the cell code for column } \mathrm{J} \text { at the } \\
\text { last date in the time series e.g. }=\mathrm{J} 128 \\
\text { would be appropriate for a record with a } \\
127 \text { day extended time series period }\end{array}$ & $\begin{array}{l}\text { This cell value will change depending on } \\
\text { the value of the constant } C \text {. Initially the } \\
\text { number showing will be an artefact of } \\
\text { the entry in cell } \mathrm{O} 2 \text { until the solver } \\
\text { routine has been run }\end{array}$ \\
\hline O7 & $\begin{array}{l}=\mathrm{SUM}(\mathrm{H} 2: \mathrm{H} \#) \text { where \#\# is the row } \\
\text { number corresponding to the last time } \\
\text { step in the time series }\end{array}$ & $\begin{array}{l}\text { Total erosion based on sum of all values } \\
\text { of } R\left(\mathrm{~kg} \mathrm{~m}^{-2}\right) \text {. This is the final result but } \\
\text { should only be recorded after the solver } \\
\text { routing has been run for the worksheet } \\
\text { for the specific sample point }\end{array}$ \\
\hline
\end{tabular}

Table 4.6 Model output data using the demonstration dataset in Table 4.2 (where $P=1.61$ and $P$ ' $=0.82$ )

\begin{tabular}{l|l|l|l}
\hline Sample ID & $\begin{array}{l}\text { PDM soil redistribution } \\
\text { amount (no particle size } \\
\text { correction) }\left(\mathrm{kg} \mathrm{m}^{-2}\right)\end{array}$ & $\begin{array}{l}\text { PDM soil redistribution } \\
\text { amount (particle size } \\
\text { corrected Taylor et al. } \\
\text { 2014) }\left(\mathrm{kg} \mathrm{m}^{-2}\right)\end{array}$ & $\begin{array}{l}\text { PDM soil redistribution } \\
\text { amount (particle size } \\
\text { corrected Yang et al. } \\
\text { 2013) }\left(\mathrm{kg} \mathrm{m}^{-2}\right)\end{array}$ \\
\hline 1 & -7.9 & -3.9 & -4.9 \\
\hline 2 & -2.1 & -1.3 & -1.3 \\
\hline 3 & -4.2 & -2.3 & -2.6 \\
\hline 4 & -6.7 & -3.4 & -4.1 \\
\hline 5 & -4.1 & -2.3 & -2.5 \\
\hline 6 & -4.7 & -2.6 & -2.9 \\
\hline 7 & -2.8 & -1.6 & -1.7 \\
\hline 9 & -2.1 & -1.2 & -1.3 \\
\hline 10 & -3.5 & -2.0 & -2.2 \\
\hline 11 & -1.4 & -0.8 & -0.9 \\
\hline & 5.7 & 4.5 & 3.2 \\
\hline
\end{tabular}




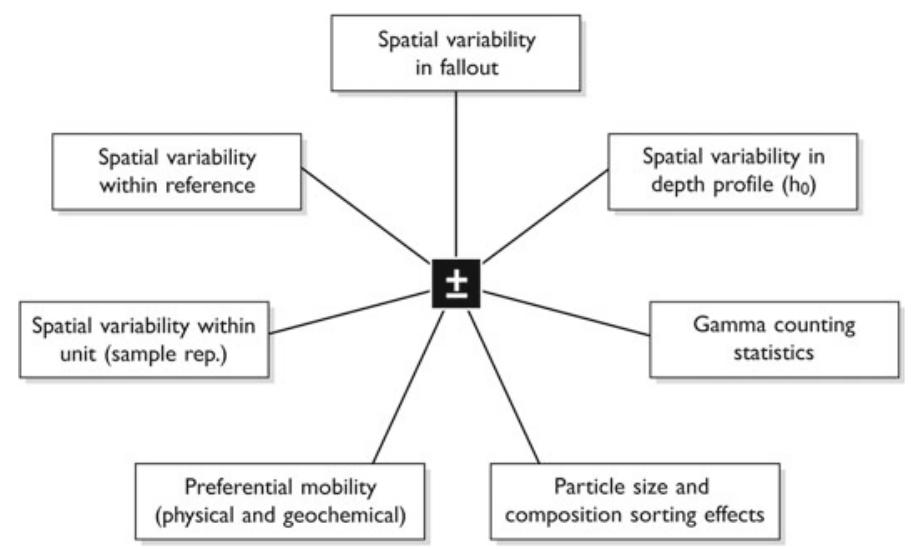

Fig. 4.5 Potential sources of uncertainty in ${ }^{7}$ Be-based estimates of soil erosion (Taylor et al. 2013)

and more relevant approach is to work with the uncertainty derived from repeated reference inventory measurements. Herein, the coefficient of variation between cores represents a real-world measure of local variability which should be accounted for in erosion estimates. In practice, the model can be run with the upper and lower limits of the reference inventory and the range of outputs used accordingly for each sample point. It should be noted that results from points that differ marginally from the inventory might switch between eroding and depositing depending in reference uncertainty. Similarly, where a spatial integration approach (see Chap. 2) has been adopted in plot sampling, variability in inventory within zones can be considered. Whichever approach is selected, the user must report what was performed with full transparency.

Any approach taken to determine and report uncertainty will have inevitable sitespecific and study-specific caveats. Users are encouraged to explore potential sources of uncertainty and undertake suitable sensitivity analysis when running conversion models to convince the scientific and stakeholder communities of data quality and the environmental relevance of results.

\section{Glossary}

Profile Distribution Model (PDM) Simple model to convert ${ }^{7}$ Be inventory loss into soil erosion amounts by linking inventory change to the depth profile to derive the mass depth of soil loss. This model is applied to single events of short period of time.

Extended time series model Improved conversion model that permits the effect of radioactive decay on soil erosion rate 
Sensitivity analysis

estimates using ${ }^{7} \mathrm{Be}$ over a longer period (e.g. wet season) to be accounted for.

Process to link uncertainty in the output of a model to different sources of uncertainty in its inputs with the aim of an increased understanding of the relationships between input and output variables.

\section{References}

Blake, W. H., Wallbrink, P. J., Wilkinson, S. N., Humphreys, G. S., Doerr, S. H., Shakesby, R. A., et al. (2009). Deriving hillslope sediment budgets in wildfire-affected forests using fallout radionuclide tracers. Geomorphology, 104, 105-116.

Blake, W. H., Walling, D. E., \& He, Q. (1999). Fallout beryllium-7 as a tracer in soil erosion investigations. Applied Radiation and Isotopes, 51(5), 599-605.

Day, P. R. (1965). Particle fractionation and particle-size analysis. In C. A. Black (Ed.), Methods of soil analysis, Part 1 (pp. 545-567). Madison, Wisconsin: American Society of Agronomy, Inc.

He, Q., \& Walling, D. E. (1996). Interpreting particle size effects in the adsorption of Cs-137 and unsupported $\mathrm{Pb}-210$ by mineral soils and sediments. Journal of Environmental Radioactivity, 30(2), 117-137.

He, Q., Walling, D. E., \& Wallbrink, P. J. (2002). Alternative methods and radionuclides for use in soil-erosion and sedimentation investigations. In F. Zapata (Ed.), Handbook for the assessment of soil erosion andsedimentation using environmental radionuclides (pp. 185-215). Dordrecht, Germany: KluwerAcademic Publishers.

Morgan, R. P. C. (2001). A simple approach to soil loss prediction: a revised Morgan-Morgan-Finney model. CATENA, 44(4), 305-322.

Porto, P., \& Walling, D. E. (2014). Use of ${ }^{7}$ Be measurements to estimate rates of soil loss from cultivated land: Testing a new approach applicable to individual storm events occurring during an extended period. Water Resources Research, 50(10), 8300-8313.

Schuller, P., Walling, D. E., Iroume, A., \& Castillo, A. (2010). Use of beryllium-7 to study the effectiveness of woody trash barriers in reducing sediment delivery to streams after forest clearcutting. Soil \& Tillage Research, 110(1), 143-153.

Taylor A. (2012) The environmental behaviour of beryllium-7 and implications for its use as a sediment tracer. Ph.D. thesis, University of Plymouth, UK.

Taylor, A., Blake, W. H., Smith, H. G., Mabit, L., \& Keith-Roach, M. J. (2013). Assumptions and challenges in the use of fallout beryllium-7 as a soil and sediment tracer in river basins. Earth-Science Reviews, 126, 85-95.

Taylor, A., Blake, W. H., \& Keith-Roach, M. J. (2014). Estimating Be-7 association with soil particle size fractions for erosion and deposition modelling. Journal of Soils and Sediments, 14(11), 1886-1893.

Walling, D. E., \& He, Q. (1999). Improved models for estimating soil erosion rates from ${ }^{137} \mathrm{Cs}$ measurements. Journal of Environmental Quality, 28, 611-622.

Walling, D. E., He, Q., \& Appleby, P. G. (2002). Conversion Models for Use in Soil-Erosion, SoilRedistribution and Sedimentation Investigations. In F. Zapata (Ed.), Handbook for the assessment of soil erosion and sedimentation using environmental radionuclides (pp. 111-164). Dordrecht, The Netherlands: Kluwer.

Walling, D. E., He, Q., \& Blake, W. (1999). Use of Be-7 and Cs-137 measurements to document short- and medium-term rates of water-induced soil erosion on agricultural land. Water Resources Research, 35(12), 3865-3874. 
Walling, D. E., Schuller, P., Zhang, Y., \& Iroume, A. (2009). Extending the timescale for using beryllium 7 measurements to document soil redistribution by erosion. Water Resources Research, 45.

Yang, M.-Y., Walling, D. E., Sun, X.-J., Zhang, F.-B., \& Zhang, B. (2013). A wind tunnel experiment to explore the feasibility of using beryllium-7 measurements to estimate soil loss by wind erosion. Geochimica et Cosmochimica Acta, 114, 81-93.

Yin, S., Xie, Y., Nearing, M. A., \& Wang, C. (2007). Estimation of rainfall erosivity using 5-to 60-minute fixed-interval rainfall data from China. CATENA, 70(3), 306-312.

The opinions expressed in this chapter are those of the author(s) and do not necessarily reflect the views of the International Atomic Energy Agency, its Board of Directors, or the countries they represent.

Open Access This chapter is licensed under the terms of the Creative Commons Attribution 3.0 IGO License (https://creativecommons.org/licenses/by/3.0/igo/), which permits use, sharing, adaptation, distribution and reproduction in any medium or format, as long as you give appropriate credit to the International Atomic Energy Agency, provide a link to the Creative Commons licence and indicate if changes were made.

The use of the International Atomic Energy Agency's name, and the use of the International Atomic Energy Agency's logo, shall be subject to a separate written licence agreement between the International Atomic Energy Agency and the user and is not authorized as part of this CC-IGO licence. Note that the link provided above includes additional terms and conditions of the licence.

The images or other third party material in this chapter are included in the chapter's Creative Commons licence, unless indicated otherwise in a credit line to the material. If material is not included in the chapter's Creative Commons licence and your intended use is not permitted by statutory regulation or exceeds the permitted use, you will need to obtain permission directly from the copyright holder.

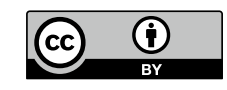

